\title{
High accuracy (stable isotope dilution) measurements of lead in serum and cerebrospinal fluid
}

\author{
W I MANTON' AND J D COOK \\ From the Mass Spectrometry Laboratory, ' University of Texas at Dallas, Richardson, Texas 75080, and \\ Department of Neurology, ${ }^{2}$ University of Texas Health Science Center, Dallas, Texas 75235, USA
}

ABSTRACT The concentration of lead in blood, serum, cerebrospinal fluid, and urine was measured in patients with neurological disease and in control subjects including cases of plumbism. A plot of blood lead versus serum lead resembles the familiar curves of blood lead versus either free erythrocyte porphyrin or urinary $\delta$-aminolaevulinic acid in that serum lead is constant up to a blood lead concentration of $40 \mu \mathrm{g} / \mathrm{dl}(2 \mu \mathrm{mol} / \mathrm{l})$ and rises steeply thereafter. The serum lead concentrations yield renal clearances in the range $5-22 \mathrm{ml} / \mathrm{min}$ in agreement with values obtained with radiolead on man and predicted from animal studies. The lead content of cerebrospinal fluid is consistently less than that of serum, averaging $50 \%$ of the serum concentration for blood leads of less than $20 \mu \mathrm{g} / \mathrm{dl}(1 \mu \mathrm{mol} / \mathrm{l})$ but rising to $80-90 \%$ in cases of plumbism. Patients with motor neurone disease could not be distinguished from those with other neurological diseases on the basis of the lead content of their serum or cerebrospinal fluid.

In 1925 Aub et al reported that $80 \%$ of the lead in blood resided in the plasma. ${ }^{1}$ Their method of assay, titration, was elaborate, used many potentially contaminating reagents, and was soon replaced by the colorimetric agent dithizone, which showed that most of the lead in blood was in fact bound to the red cells. Disagreement persisted into the 1940 s, however, about the precise value for the partitioning, and not until the late 1950s was it firmly established that at least $90 \%$ of the lead in blood was red cell bound. The exact concentration of lead in the plasma was below the detection limit of careful workers using dithizone. Both Willoughby and Wilkins $^{2}$ and Robinson et l $^{3}$ stated that it was undetectable, below $10 \mu \mathrm{g} / \mathrm{dl}(0.5 \mu \mathrm{mol} / \mathrm{l})$. The modern instrumental technique of atomic absorption spectrophotometry has the required sensitivity, and several workers have reported plasma lead concentrations. ${ }^{4-7}$ There is general agreement that for the normal range of blood lead concentrations, 10-25 $\mu \mathrm{g} / \mathrm{dl}(0.5-1.2 \mu \mathrm{mol} / \mathrm{l})$ plasma lead ranges from 0.3 to $1 \mu / \mathrm{dl}(15-50 \mathrm{nmol} / \mathrm{l})$.

The concentration of lead in the plasma has generally been cautiously reported, because a careful worker knew that the figure could not exceed the difference between that in whole blood and packed

Received 25 July 1983

Accepted 22 August 1983 red cells. Without any such constraint, though it would seem reasonable that lead in cerebrospinal fluid should approximate that in plasma, incredibly high values of cerebrospinal fluid lead are found in earlier reports. In 1937 Schmitt and Basse reported $15-38 \mu \mathrm{g} / \mathrm{dl}(0.7-1.8 \mu \mathrm{mol} / \mathrm{l})$ for normal subjects and up to $500 \mu \mathrm{g} / \mathrm{dl}(24 \mu \mathrm{mol} / \mathrm{l})$ in cases of lead intoxication. ${ }^{8}$ Their contemporaries, Cantarow and Trumper, reported much the same values. ${ }^{9}$ In 1952 , in a careful study using dithizone, Butler was unable to reproduce the excessively high values reported in lead intoxication, but in patients with neurological disease he found $1-32 \mu \mathrm{g} / \mathrm{dl}(0.05-1.5 \mu \mathrm{mol} / \mathrm{l}) .^{10}$ This range appears to be confirmed by the modern worker using atomic absorption spectrophotometry, Conradi et al ${ }^{11}$ reporting 0.9-5 $\mu \mathrm{g} / \mathrm{dl}(0.05-0.25$ $\mu \mathrm{mol} / \mathrm{l})$ and House et al ${ }^{12}$ reporting less than 1 to nearly $30 \mu \mathrm{g} / \mathrm{dl}(0 \cdot 05-1 \cdot 5 \mu \mathrm{mol} / \mathrm{l})$. Recently, however, Conradi et al have revised their figures downwards by a factor of 3 to $4 .{ }^{13}$

The absolute concentrations of lead in the plasma and cerebrospinal fluid are of interest with regard to the general problem of subclinical lead poisoning. Ever since it was appreciated that lead was a neurotoxin, exposure to the metal has, from time to time, been advanced as an explanation of various idiopathic neurological diseases. The longest lasting of such ideas is that lead in some manner precipitates motor neurone disease. Wilson developed the 
hypothesis in 1907 after observing that several cases of the disease followed lead poisoning. ${ }^{14}$ Recent reports of raised concentrations of lead in the plasma $^{6}$ and cerebrospinal fluid ${ }^{1113}$ and in the anterior horns of the spinal cords of patients with motor neurone disease ${ }^{15}$ have focused new attention on the hypothesis and have given it some credibility. We believed that these claims of raised lead in motor neurone disease needed to be verified, because most modern instrumental techniques, though sensitive, have the common failing that the signal from an unknown sample is compared with that from a known external standard. If the sample and standard are not virtually identical, interferences may occur that will cause either over- or underestimation of the amount of element in the sample. The method that we have used, mass spectrometric stable isotope dilution, is unique because it uses an internal standard in the form of an enriched stable isotope of the element to be determined. A precisely known amount of this isotope, or tracer, is added to the tissue. The tissue is decomposed and the element, now a mixture of atoms from both the tracer and the natural element, is chemically purified and is then isotopically analysed on a mass spectrometer. From the change brought about in the isotope ratio of the tracer, the amount of element in the tissue may be calculated. In trace analysis stable isotope dilution comes closest to an absolute method.

\section{Methods}

\section{EXPERIMENTAL DESIGN}

We found that heparinised plasma was often pink from haemolysis and contained about $10 \%$ more lead than serum. To avoid this problem and the problem of how to apportion the heparin blank (our heparin contained $4.1 \mathrm{ng} \mathrm{Pb} / \mathrm{ml}(0.2 \mathrm{nmol} / \mathrm{l}))$ we have worked only with serum.

Sufficient work had been carried out with radiolead to enable us to devise two straightforward checks of our measurements. The simpler is that our absolute concentration of lead in the serum should yield the same fraction with respect to whole blood as obtained with radiolead. We therefore also measured whole blood concentrations of lead from our patients by stable isotope dilution. Rather more subtle is the measurement of the renal clearance of lead from the serum. Vander $e$ al and Victery et al have shown that lead is handled in the kidney of the dog by a combination of filtration, tubular secretion, and reabsorption. ${ }^{16-18}$ They found ultrafilterability in the range $20-30 \%$ and reabsorption in the range $60-90 \%$. Secretion is insignificant insofar as most secreted lead is reabsorbed. Accordingly, if our serum concentrations are correct our clearances should imply the same processes and be much less than the glomerular filtration rate. As it has been shown that tin may influence the renal clearance of lead, ${ }^{19}$ we measured urinary tin also. To extend the range of our measurements we have included measurements on lead workers and on two cases of plumbism investigated in this laboratory.

Samples were obtained at the convenience of the attending physician, and the question arose regarding the effect of diurnal or longer term fluctuations on the scatter of the results. To answer this, we measured the serum lead at intervals from several control subjects. One of these undertook a series of 36 hour fasts, enabling us to investigate the effect of prandial lead on the concentration of lead in the plasma. A similar question arose regarding the equilibration of lead between cerebrospinal fluid and plasma and its effect on the ratio of cerebrospinal fluid lead to plasma lead. Two patients undergoing chelation therapy provided a partial answer.

\section{PATIENTS}

The 36 patients taking part in this study were either followed up at the Dallas Veterans' Medical Center or the University of Texas Health Science Center at Dallas. Twenty five patients had other neurological disease or symptoms not involving heavy metal intoxication or motor neurone disease. The history, physical examination, and laboratory studies of the 11 patients diagnosed with motor neurone disease all meet the criteria outlined by Rowland ${ }^{20}$ for the diagnosis of motor neurone disease. Two cases were confirmed at necropsy. Informed consent was obtained from all subjects used in this study.

\section{ANALYTICAL METHODS}

Thirty millilitres of blood were drawn using an 18 gauge needle and a polypropylene syringe. Five $\mathrm{ml}$ were expelled into a $100 \mathrm{ml}$ Tefion FEP bottle and the remainder into a Pyrex centrifuge tube. After retraction of the clot the blood was centrifuged and the serum transferred with a clean polypropylene pipette to a similar Teflon bottle. Approximately $10 \mathrm{ml}$ of cerebrospinal fluid was allowed to drip from the needle hub into a Teflon bottle. Twenty four hour urines were collected in acid washed polyethylene jugs and a $10 \%$ aliquot was transferred to a $500 \mathrm{ml}$ Teflon bottle. The tracer, $99.98 \%$ pure ${ }^{206} \mathrm{~Pb}$, was added to each sample before being decomposed by boiling in $70 \%$ nitric acid. Lead was separated from blood and urine by coprecipitation with barium nitrate followed by electrodeposition, and from serum and cerebrospinal fluid by ion exchange. These techniques and those for tin are described elsewhere.${ }^{19}$ Isotope ratios were measured 
on a $30 \mathrm{~cm}$ radius, $60^{\circ}$ sector field, single focusing mass spectrometer fitted with a Faraday cup collector.

Blanks were measured with each batch of five samples. Those associated with blood and urine measurements ranged from 1 to $2 \mathrm{ng} \mathrm{Pb}(0 \cdot 05-0 \cdot 1$ nmol) and were negligible. To minimise the blank associated with serum and cerebrospinal fluid measurements, we gave the Teflon bottles, which we found had a memory, an additional cleaning by boiling double distilled nitric acid in them twice. The blank associated with the decomposition ranged from 0.5 to $0.8 \mathrm{ng}(24-38 \mathrm{pmol})$ and that associated with the ion exchange column was reproducible at $0.3 \mathrm{ng}$ (14 pmol).

A special problem was how to assess the blank associated with the collection of serum. In vitro, red cells rapidly bind radiolead suggesting that they might also scavenge any contaminating lead. We checked this by drawing two $30 \mathrm{ml}$ blood samples from a subject and adding to one Pyrex tube $10 \mathrm{ng}$ $(0.5 \mathrm{nmol})$ of the weak $x$ ray emmitter ${ }^{205} \mathrm{~Pb}$. We identified by mass spectrometry only a trace of ${ }^{205} \mathrm{~Pb}$ in the serum and, what is more, obtained identical concentrations of lead in the two samples even though we had "contaminated" the one with about the same quantity of lead that it originally contained. This result led us to believe that in assays for lead in serum no extraordinary precautions have to be taken with regard to needles and syringes or the vessels used for clotting.

We found that cerebrospinal dripped through a metal stopcock (brass, with soldered luer connections) contained 100 times more lead than cerebrospinal dripped through the needle alone. Our cerebrospinal fluid samples were taken after those taken for routine clinical tests in the belief that any contamination would have already been flushed out of the needle.

Taking all sources of error into account we believe that the figures for the concentrations of lead in serum and cerebrospinal fluid have not more than $20 \%$ uncertainty associated with them. For blood and urine the uncertainty is less, $1-2 \%$.

\section{Results}

It is seen from fig 1 that, for an individual eating ad libitum, the ratio of serum lead to blood lead may vary by a factor of 2 and that between individuals a factor of 5 or more may exist. For subject 3, however, the fraction of lead in serum was considerably reduced and a smaller range was observed when he was fasting.

Renal clearances (table 1) were measured on subjects with serum lead concentrations varying from

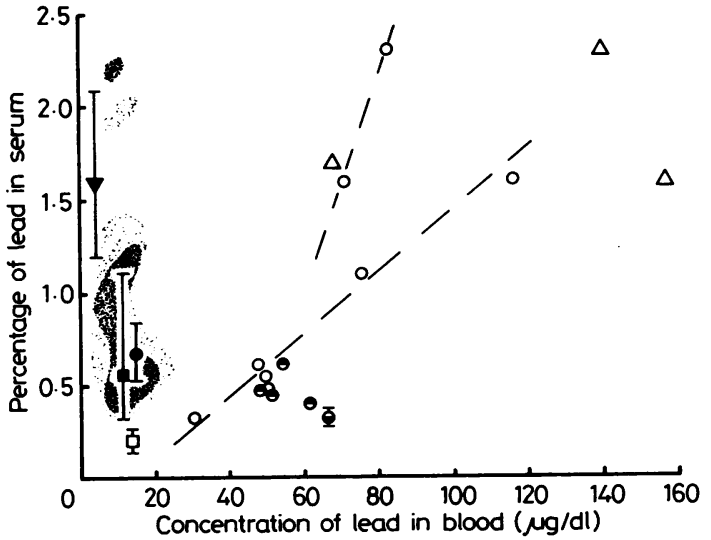

Fig 1 Relation between concentration of lead in blood and percentage of lead in serum. Light stippling: Field of diseased controls and healthy subjects. Larger area contains 15 diseased and 10 healthy subjects. Smaller area contains two healthy subjects. Heavy stippling: Field of patients with motor neurone disease. Larger area contains 10 patients, the smaller area one. Symbols with bars designate healthy subjects sampled repetitively. Symbol indicates mean, bar range of serum values. Range of blood concentrations within horizontal dimension of symbols. Solid triangle: subject 7, three measurements; solid square: subject 3 , eating freely, five measurements; open square: subject 3 , fasting, six measurements; solid circle: subject 10, two measurements; half circle: subject 11, three measurements; other symbols: half circle: lead workers, open circle: subject 12. Lines drawn through points refer to episodes of lead poisoning and subsequent treatment. Open triangle: subject 13.

0.03 to $3.3 \mu \mathrm{g} / \mathrm{dl}(1.5-150 \mathrm{nmol} / \mathrm{l})$. The values obtained ranged from 5 to $22 \mathrm{ml} / \mathrm{min}$. No dependence on serum lead concentration was noted and clearances measured on subject 3 were similar whether he was fasting or not.

With the exception of subject 8 , urinary tin excretions ranged from $2 \cdot 0$ to $7 \cdot 5 \mu \mathrm{g}(17-64 \mathrm{nmol}) / 24$ hours with subject 3 having an excretion approximately double that of the other subjects. On the basis of his urinary tin, subject 8 is believed to have been exposed to organic tin. A second sample obtained 14 months after the first shows him to be excreting $13 \mu \mathrm{g}(0 \cdot 1 \mu \mathrm{mol}) / 24$ hours. No effect on his renal handling of lead is apparent.

In fig 2 absolute concentrations of lead in serum are plotted against concentrations of lead in blood. At a blood lead concentration of $10 \mu \mathrm{g} / \mathrm{dl}(0.5$ $\mu \mathrm{mol} / \mathrm{l})$ serum lead is $0 \cdot 25 \mu \mathrm{g} / \mathrm{dl}(12 \mathrm{nmol} / \mathrm{l})$ and then rises as a steep function of blood lead concentration. Several subjects with blood lead concentrations below $20 \mu \mathrm{g} / \mathrm{dl}(1 \mu \mathrm{mol} / \mathrm{l})$ had serum lead con- 
Table 1 Renal clearances of lead from serum

\begin{tabular}{|c|c|c|c|c|c|}
\hline Subject & Disease & Serum $P b(\mu g / d l)$ & Urine $\mathrm{Pb}(\mu \mathrm{g} / 24 h)$ & Urine $S n(\mu g / 24 h)$ & CPbs $\mathrm{ml} / \mathrm{min}$ \\
\hline $\begin{array}{l}1 \\
2 \\
3\end{array}$ & $\begin{array}{l}\text { Normal } \\
\text { Sensory neuropathy } \\
\text { Normal: eating freely } \\
\text { fasting }\end{array}$ & $\begin{array}{l}0.032 \\
0.045 \\
0.039 \\
0.042 \\
0.054 \\
0.034 \\
0.027 \\
0.020 \\
0.029 \\
0.025\end{array}$ & $\begin{array}{c}5 \cdot 1 \\
8 \cdot 4 \\
12 \\
13 \\
14 \\
8 \cdot 3 \\
7 \cdot 9 \\
6 \cdot 3 \\
6 \cdot 8 \\
5 \cdot 8\end{array}$ & $\begin{array}{c}2.4 \\
2.0 \\
4.8 \\
6.5 \\
6.3 \\
14 \\
5.9 \\
5.6 \\
7.5 \\
-\end{array}$ & $\begin{array}{l}11 \\
13 \\
21 \\
22 \\
18 \\
17 \\
20 \\
22 \\
16 \\
16\end{array}$ \\
\hline 4 & Normal & 0.051 & $8 \cdot 1$ & $3 \cdot 9$ & 11 \\
\hline 5 & Normal & 0.052 & $6 \cdot 5$ & $3 \cdot 2$ & $8 \cdot 7$ \\
\hline 6 & Motor neurone disease & 0.052 & 10 & $1 . \overline{9}$ & 14 \\
\hline 7 & Normal & 0.056 & $4 \cdot 1$ & $2 \cdot 0$ & $5 \cdot 1$ \\
\hline 8 & Motor neuropathy & 0.070 & 16 & 112 & 16 \\
\hline & & 0.054 & $8 \cdot 0$ & 13 & 10 \\
\hline 9 & Motor neurone disease & 0.076 & 14 & - & 14 \\
\hline 10 & Normal & 0.120 & 14 & $3 \cdot 7$ & $8 \cdot 2$ \\
\hline 11 & Lead worker & 0.237 & 47 & $3 \cdot 0$ & 14 \\
\hline 12 & Plumbism & 1.86 & 235 & - & $8 \cdot 8$ \\
\hline 13 & Plumbism & $3 \cdot 33$ & 405 & - & $8 \cdot 4$ \\
\hline
\end{tabular}

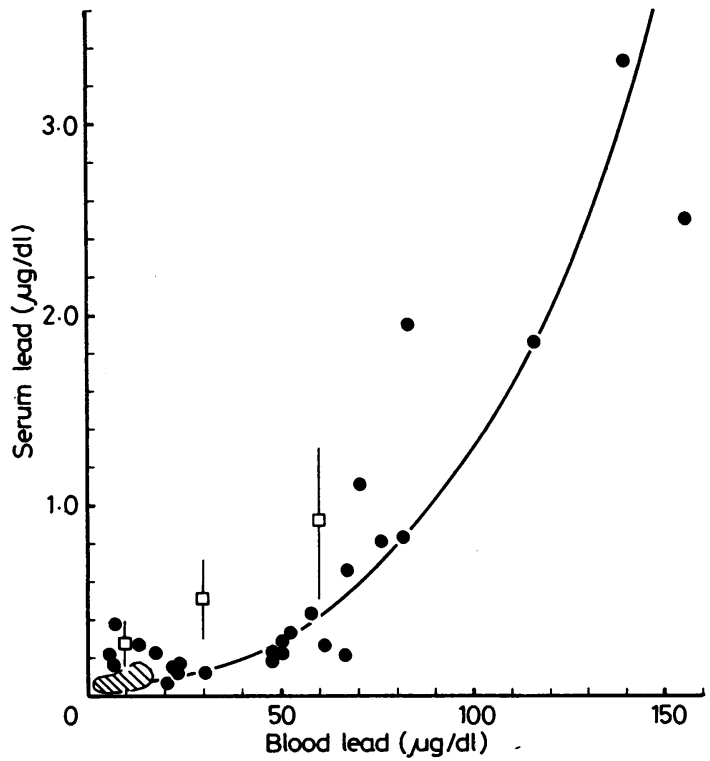

Fig 2 Plot of blood lead concentration versus serum lead concentration. Hatched area contains 23 points. Open squares represent mean values and standard deviations reported by de Silva ${ }^{7}$ with the abscissa being midpoint of each of her ranges. Values obtained from subject 3 while fasting are not shown.

centrations in the range of those who had between 50 and $70 \mu \mathrm{g} \mathrm{Pb} / \mathrm{dl}(2 \cdot 4-3.4 \mu \mathrm{mol} / \mathrm{l})$ in their blood. For the subject who fasted, a serum lead concentration of $0.021 \mu \mathrm{g} / \mathrm{dl}(1.0 \mathrm{nmol} / \mathrm{l})$ was measured for an average blood lead of concentration of $13.5 \mu \mathrm{g} / \mathrm{dl}$ $(0.65 \mu \mathrm{mol} / \mathrm{l})$.

In fig 3 concentrations of lead in serum are plotted 
against those in cerebrospinal fluid. The lead content of cerebrospinal fluid is consistently less than that of serum. Only patients who had undergone chelation therapy within 24 hours of measurement show a lead concentration in the cerebrospinal fluid greater to or equal to that in serum.

\section{Discussion}

ACCURACY OF SERUM LEAD DETERMINATION Our result that the serum lead concentration is about $1 \%$ of the whole blood concentration agrees well with the figures of $0.5-1.5 \%$ obtained by Hursch $e t a l^{21}$ from experiments with ${ }^{212} \mathrm{~Pb}$ in vitro and with the estimate of $1 \%$ of Chamberlain $e^{2} a^{22}$ which was based on a series of experiments with ${ }^{203} \mathrm{~Pb}$ in vivo.

Our renal clearances of $5-22 \mathrm{ml} / \mathrm{min}$ were obtained from individuals with body weights ranging from 50 to $100 \mathrm{~kg}$ and excreting 1.4 to $2.3 \mathrm{~g}$ of creatinine a day. They are uncorrected as we found that our serum creatinine assay was unreliable. This range is in general agreement with the measurement of Chamberlain $e t a^{22}$ of renal clearance of radiolead in man. For a single individual, they obtained $30 \mathrm{ml} / \mathrm{min}$ five to 46 hours after injection with ${ }^{203} \mathrm{~Pb}$. For six individuals, they calculated a mean clearance of $14 \mathrm{ml} / \mathrm{min}$ over the period 3-14 days after injection. Of the various protocols used by Vander $e t a^{16}$ and Victery $e t a^{17}$ that corresponded closest to man with typical blood lead concentrations was one in which dogs were administered ${ }^{203} \mathrm{~Pb}$ in an infusion of $2.5 \mu \mathrm{g}(0.12 \mu \mathrm{mol})$ carrier lead per $\mathrm{kg} / \mathrm{min} .{ }^{17}$ After one hour the animals showed an increment in blood lead concentration of $1.25 \mu \mathrm{g} / \mathrm{dl}(60 \mathrm{nmol} / \mathrm{l})$ above their endogenous blood lead concentration (which was not measured). In these animals $30 \%$ of the lead was ultrafilterable and $62 \%$ of the filtered lead was reabsorbed. Applied to the nominal human glomerular filtration rate of $125 \mathrm{ml} / \mathrm{min}$ these figures give a renal clearance of $14 \mathrm{ml} / \mathrm{min}$, in the middle of our range of uncorrected values. Vander et al have also shown that the ultrafilterability and thus the renal clearance of lead decreases with the total amount of lead infused. ${ }^{16}$ Accordingly, our findings that the cases of lead intoxication had among the lowest clearances is consistent with their results.

The good agreement between our clearances and those obtained with radiolead testify to the accuracy of our measurement of lead in serum. If we had obtained values similar to those reported by atomic absorption our clearances would have been on average five times smaller or around $3 \mathrm{ml}$ a minute. A value similar to the $0.002 \mu \mathrm{g} / \mathrm{dl}(0.1 \mathrm{nmol} / \mathrm{l})$ reported by Everson and Patterson ${ }^{23}$ for a normal subject would have produced a clearance approximating the glomerular filtration rate.

\section{FRACTION OF BLOOD LEAD IN SERUM}

A plot of the percentage of lead in serum versus lead in whole blood is shown in fig 1 which includes data from lead workers and two cases of lead intoxication studied in this laboratory. The subjects with low blood lead concentrations show a large range in the fraction of lead in serum, but this range may be for the most part put down to natural time dependent variations, as those individuals who were sampled repetitively show almost as large a range. The explanation probably lies in lead being absorbed into plasma after eating. This effect was observed by de Silva ${ }^{7}$ and is supported by our observations that during fasting serum lead concentration and urinary lead excretion are almost halved. Another factor could be the return of lead to plasma from the extracellular fluid as noted by Chamberlain et al.$^{24}$ It follows that at low blood lead concentrations the true value for the partitioning can be obtained only from a fasting subject. At higher concentrations resulting from abnormal exposure the effect of prandial lead is reduced and the observed partitioning is probably close to the equilibrium value. Although our data are limited and there are large variations between individuals, we infer that at a blood lead concentration of $10 \mu \mathrm{g} / \mathrm{dl}(0.5 \mu \mathrm{mol} / \mathrm{l})$, about $0.2 \%$ of the lead resides in plasma at equilibrium. At $50 \mu \mathrm{g} \mathrm{Pb} / \mathrm{dl}(2.5 \mu \mathrm{mol} / \mathrm{l})$ this figure is about $0.4 \%$ and rises to between $1.5 \%$ and $2 \%$ at a blood lead concentration of $100 \mu \mathrm{g} / \mathrm{dl}(5 \mu \mathrm{mol} / \mathrm{l})$. This variation cannot be explained by a change in haematocrit and indicates that the partitioning of lead between plasma and red cells is not constant, as de Silva ${ }^{7}$ assumed, but increases as a function of blood lead concentration.

\section{LEAD CONTENT OF SERUM}

The relation between lead in serum and whole blood is similar to the curves reported for free erythrocyte porphyrin (FEP) in blood ${ }^{25}$ and $\delta$-aminolaevulinic acid ( $\delta$-ALA) in urine ${ }^{26}$ insofar as all show little change between blood lead concentrations of 10 and $40 \mu \mathrm{g} \mathrm{Pb} / \mathrm{dl}(0 \cdot 5-2 \mu \mathrm{mol} / \mathrm{l})$ but rise steeply thereafter. This result is not unexpected if the toxicity of lead is exerted by the moiety present in plasma. Hitherto the flat portions of the blood FEP and urinary $\delta$-ALA curves have been attributed to instrumental insensitivity or to the presence of a constant background of these substances in blood. On the basis of our measurements we suggest that both are, in fact, accurately measuring the quantity of lead in the plasma of individuals eating ad libitum. 
Table 2 Comparison of lead content of blood, serum, and cerebrospinal fuid between patients with motor neurone disease and controls

\begin{tabular}{|c|c|c|c|c|}
\hline Tissue & $\begin{array}{l}M N \\
N o\end{array}$ & ${ }^{s} \bar{X} \pm \sigma$ & $\begin{array}{l}\text { Controls } \\
\text { No }\end{array}$ & $\bar{X} \pm \sigma$ \\
\hline $\begin{array}{l}\text { Blood }(\mu \mathrm{g} / \mathrm{dl}) \\
\text { Serum }(\mu \mathrm{g} / \mathrm{dl}) \\
\text { Cerebrospinal fluid ( } \mu \mathrm{g} / \mathrm{dl}) \\
\text { Serum/blood }(\%) \\
\text { Cerebrospinal fluid/serum }\end{array}$ & $\begin{array}{r}11 \\
11 \\
10 \\
11 \\
9\end{array}$ & $\begin{array}{ll}11.7 & \pm 3.8 \\
0.092 & \pm 0.047 \\
0.037 & \pm 0.021 \\
0.85 & \pm 0.51 \\
0.48 & \pm 0.14\end{array}$ & $\begin{array}{r}25 \\
15 \\
15 \\
15 \\
7\end{array}$ & $\begin{array}{ll}13.3 & \pm 5.1 \\
0.11 & \pm 0.05 \\
0.054 & \pm 0.038 \\
0.91 & \pm 0.29 \\
0.46 & \pm 0.20\end{array}$ \\
\hline
\end{tabular}

\section{LEAD CONTENT OF CEREBROSPINAL FLUID}

The concentration of lead in serum is plotted against that in cerebrospinal fluid in fig 3 and the means and ranges for patients with blood lead concentrations less than $20 \mu \mathrm{g} / \mathrm{dl}(1 \mu \mathrm{mol} / \mathrm{l})$ are summarised in table 2 . It is seen that the lead content of the cerebrospinal fluid is consistently less than that of the serum, averaging half its concentration for blood lead concentrations less than $20 \mu \mathrm{g} / \mathrm{dl}(1 \mu \mathrm{mol} / \mathrm{l})$ and rising to $80-90 \%$ of the serum value in plumbism.

We take our observation that the highest fractions of lead in cerebrospinal fluid with respect to serum were found in patients who had just undergone or were undergoing chelation therapy to imply that the equilibration between plasma and cerebrospinal fluid is slow, of the order of hours. Such slow equilibration would also account for the variability observed in the cerebrospinal fluid lead to serum lead fraction among the patients we had studied.

O'Tuama et al have shown that the choroid plexus, meninges, and paraventricular tissue of guinea pigs avidly accumulate injected radiolead and argue that the role of these tissues is to protect the brain from lead. ${ }^{27}$ In this light the lead content of the cerebrospinal fluid at $46 \pm 20 \%$ that of the serum is surprisingly high. In fact, this figure approximates the fraction of ultrafilterable lead in the serum as measured by Vander et al in dogs. ${ }^{16}$

\section{LEAD AND MOTOR NEURONE DISEASE}

We have found nothing to substantiate the claims of Conradi et $a^{611} 12$ that the concentrations of lead in the serum and cerebrospinal fluid of patients with motor neurone disease are raised. In table 2 the standard deviation of each of the parameters measured overlaps; in figs 1 and 3 (a) the principal field of the patients with motor neurone disease lies within the field of the control subjects. What is more, the concentrations that we have measured are much lower than those reported by atomic absorption spectrophotometry. In the case of serum our figures are five times less; in the case of cerebrospinal fluid our concentrations are one hundred times less than those of House et al $^{12}$ and ten times less than the revised figures of Conradi et al. ${ }^{13}$
It is difficult to compare our results with those of de Silva who reported plasma lead versus erythrocyte lead rather than plasma lead versus blood lead concentrations. In her table 3 , however, she gives mean plasma lead concentrations for ranges of whole blood concentrations. These are plotted in fig 2 with the abscissa being the midpoint of each range. It is clear that her plasma lead concentrations are about twice ours. When so plotted her data imply a plasma lead concentration of $0 \cdot 1 \mu \mathrm{g} \mathrm{Pb} / \mathrm{dl}$ ( $5 \mathrm{nmol} / \mathrm{l})$ at a blood lead of zero, which is suggestive of systematic laboratory contamination. Indeed, in assays for lead the one probable source of systematic error is contamination, but none of the various workers has described his procedures sufficiently well enough for us to evaluate this possibility. For example, could the high concentrations of lead reported for the cerebrospinal fluid be due to the use of metal stopcocks during collection? The analysis of heparinised plasma rather than serum, with the possibility of leakage of lead from lysed red cells, or spurious lead signals from the complex matrix of plasma or cerebrospinal fluid may also be factors contributing to the high values reported by other workers.

The only workers who have reported values lower than ours are Everson and Patterson, who also used stable isotope dilution. ${ }^{23}$ Clearly, however, the discrepancy lies in where the heparin blank is to be subtracted. They chose to subtract theirs from the lead in plasma, whereas we believe the lead in the heparin would have been scavenged by the erythrocytes. If the blank correction is not made their results agree with ours.

This work was supported by a grant from the Muscular Dystrophy Association Inc.

\section{References}

' Aub JC, Fairhall LT, Minot AS, Reznikoff P. Lead poisoning. Medicine 1925;4:250.

${ }^{2}$ Willoughby CE, Wilkins ES. The lead content of human blood. $J$ Biol Chem 1938;124:639-57.

${ }^{3}$ Robinson MJ, Karpinski FE, Brieger $H$. The concentration of lead in plasma, whole blood and erythrocytes of infants and children. Pediatrics 1958;21:793-6. 
4 Cavalleri A, Minoia C, Pozzoli L, Baruffini A. Determination of plasma lead levels in normal people and lead-exposed workers. Br J Ind Med 1978;34:21-6.

${ }^{5}$ Cavalleri A, Minoia C, Pozzoli L, Polatti F, Bolis PF. Lead in red blood cells and plasma of pregnant women and their offspring. Environ Res 1978;17:403-8.

- Conradi S, Ronnevi LO, Vesterburg O. Increased plasma levels of lead in patients with amyotrophic lateral sclerosis compared with control subjects as determined by flameless atomic absorption spectrophotometry. J Neurol Neurosurg Psychiatry 1978;41:389-93.

${ }^{7}$ de Silva PE. Determination of lead in plasma and studies on its relationship to lead in erythrocytes. $\mathrm{Br} J$ Ind Med 1981;38:209-17.

- Schmitt F, Basse W. Bleiuntersuchungen im liquor cerebrospinalis normaler und bleikranker. Klin Wochenschr 1937;16:65-6.

- Cantarow A, Trumper M. Lead poisoning, Baltimore: Williams and Wilkins, 1944:264.

${ }^{10}$ Butler EJ. Chronic neurologic disease as a possible form of lead poisoning. J Neurol Neurosurg Psychiatry 1952;15:119-28.

"Conradi S, Ronnevi LO, Vesterberg O. Abnormal tissue distribution of lead in amyotrophic lateral sclerosis. J Neurol Sci 1976;29:259-65.

${ }^{12}$ House AO, Abbott RJ, Davidson DLW, Ferguson IT, Lenman JAR. Response to penicillamine of lead concentrations in CSF and blood in patients with motor neurone disease. $\mathrm{Br}$ Med $\mathrm{J}$ 1978;ii: 1684.

${ }^{13}$ Conradi S, Ronnevi LO, Nise G, Vesterberg O. Abnormal distribution of lead in amyotrophic lateral sclerosis: reestimation of lead in the cerebrospinal fluid. J Neurol Sci 1980;48:413-8.

14 Wilson SAK. The amyotrophy of chronic lead poisoning: amyotrophic lateral sclerosis of toxic origin. Rev Neurol Psychiatr 1907;5:441-5.

is Kurlander HM, Patten BM. Metals in spinal cord tissue of patients dying of motor neurone disease. Ann Neurol 1979;6:21-4.

${ }^{16}$ Vander AJ, Taylor DL, Kalitis K, Mouw DR, Victery W. Renal handling of lead in dogs: clearance studies. Am J Physiol 1977;233:F523-38.

17 Victery W, Vander AJ, Mouw DR. Effect of acid-base status on renal excretion and accumulation of lead in dogs and rats. Am J Physiol 1979;237:F398-407.

${ }^{18}$ Victery W, Vander AJ, Mouw DR. Renal handling of lead in dogs. Stop-flow analysis. Am J Physiol 1979;237:F408-14.

19 Manton WI, Malloy CB. Distribution of lead in body fluids after ingestion of soft solder. $\mathrm{Br} J$ Ind Med 1983;40:51-7.

${ }^{20}$ Rowland LP. Motor neurone diseases. The clinical syndromes. In: Mulder DW, ed. The diagnosis and treatment of amyotrophic lateral sclerosis. Boston: Houghton Miffin, 1980:7-35.

${ }^{21}$ Hursch J, Schraub A, Sattler E, Hofman HP. Fate of ${ }^{212} \mathrm{~Pb}$ inhaled by human subjects. Health Phys 1969;16:257-67.

${ }^{22}$ Chamberlain AC, Heard MJ, Little P, Newton D, Wells AC, Wiffen RD. Investigations into lead from motor vehicles. Harwell: UK Atomic Energy Authority, 1978. (AERE-R 9198.)

${ }^{23}$ Everson J, Patterson CC. Ultra-clean isotope dilution-mass spectrometric analyses for lead in human blood plasma indicate that most reported values are artificially high. Clin Chem 1980;26: 1603-7.

${ }^{24}$ Chamberlain AC, Clough WS, Heard MJ, Newton D, Stott ANB, Wells AC. Uptake of lead by inhalation of motor exhaust. Proc $R$ Soc Lond B 1975;192:77-110.

${ }^{25}$ Piomelli S. A micromethod for free erythrocyte porphyrins: the FEP test. J Lab Clin Med 1973;81:932-40.

${ }^{26}$ Selander S, Cramer K. Interrelationships between lead in blood, lead in urine, and ALA in urine during lead work. Br J Ind Med 1970;27:28-39.

${ }^{27}$ O'Tuama LA, Kim CS, Gatzy JT, Krigman MR, Musak P. The distribution of inorganic lead in guinea pig brain and neutral barrier tissues in control and lead-poisoned animals. Toxicol Appl Pharmacol 1976;36:1-9. 